\title{
Youth Apathy in Political Contest: A Case Study in the 2020 Gowa Regency Head Election
}

\author{
Nur Riswandy Marsuki ${ }^{1)}$, Shermina Oruh ${ }^{2)}$, Andi Agustang ${ }^{3)}$ \\ ${ }^{1)}$ Postgraduate Doctoral Degree in Sociology Universitas Negeri Makassar \\ 2) Universitas Pejuang Republik Indonesia \\ 3) Universitas Negeri Makassar \\ Corresponding Author: Nur Riswandy Marsuki, Email: riswandymarsuki91@gmail.com
}

History: Received 11/11/2021 | Revised 07/12/2021 | Accepted 04/01/2022 | Published 31/01/2022

\begin{abstract}
This study examines the political apathy that plagues youth in Gowa Regency. Political apathy is an indifference and lack of interest in politics. This research was conducted to explore the causes of apathy and alternative solutions to these problems. The apathy that afflicts young people is a serious problem that must be solved. This is because they have intellectual capital that can create social change for the better. This change can occur if youth actively participate in each stage of the contestation. The research used is qualitative research with a case study approach. Informants were selected by purposive sampling, consisting of elements of youth organizations, apathetic youth groups and the government. Collecting data through document studies, observation, in depth interviews, focus group discussions and documentation. Analysis uses the Miles and Huberman model, namely data reduction, data presentation and conclusion drawing. The results show that the causes of youth apathy towards politics include the lack of knowledge of the position of youth in development, a bad political image, the influence of the family/friendship environment and the contestants are only followed by one pair of candidates. Then alternative solutions that can be done to minimize apathy are to increase education or community-based political socialization and strengthen youth organizations as a forum for youth to develop themselves.
\end{abstract}

Keywords: Apatism, Youth, Contestation, Participation

\begin{abstract}
Abstrak. Penelitian ini mengkaji tentang apatisme politik yang melanda pemuda di Kabupaten Gowa. Apatisme politik merupakan sifat acuh tak acuh serta tidak memiliki ketertarikan terhadap politik. Penelitian ini dilakukan untuk menggali penyebab apatisme dan solusi alternatif atas permasalahan tersebut. Apatisme yang menimpa kaum muda merupakan persoalan serius yang harus ditemukan solusinya. Pasalnya, mereka memiliki modal intelektual yang dapat menciptakan perubahan sosial ke arah yang lebih baik. Perubahan ini dapat terjadi jika pemuda berpartisipasi aktif dalam setiap tahapan kontestasi. Penelitian yang digunakan adalah penelitian kualitatif dengan pendekatan studi kasus. Informan dipilih secara purposive sampling, terdiri dari unsur organisasi kepemudaan, kelompok pemuda apatis dan pihak pemerintah. Pengumpulan data melalui studi dokumen, observasi, in depth interview, focus group discussion dan dokumentasi. Analisis data menggunakan model Miles dan Huberman yakni reduksi data, penyajian data dan penarikan kesimpulan.Hasil penelitian menunjukkan bahwa penyebab apatisme pemuda terhadap politik diantaranya masih lemahnya pengetahuan atas posisi pemuda dalam pembangunan, citra politik yang buruk, pengaruh lingkungan keluarga/pertemanan dan kontestan hanya diikuti oleh satu pasang calon. Kemudian solusi alternatif yang dapat dilakukan untuk meminimalisir apatisme yakni, memassifkan pendidikan atau sosialisasi politik berbasis komunitas dan penguatan organisasi kepemudaan sebagai wadah bagi pemuda untuk mengembangkan dirinya.
\end{abstract}

Kata kunci: Apatis, Pemuda, Kontestasi, Partisipasi 


\section{INTRODUCTION}

A youthful soul is a spirited soul, a soul that has moodbooster ammunition (AcuñaDuarte, 2017). The hallmark of a young man is his fiery spirit. A young man physically has more strength than his age (Henn, Weinstein, \& Wring, 2002). Therefore, youth are included in the productive age. The age of youth is limited to the age range of 16-30 years as stated in Article 1 of Law Number 40 of 2009 concerning Youth. Along with youth services, it is directed to increase the participation and active role of youth in building themselves, society, nation and state (Nur Wardhani, 2018). Youth participation in social, cultural, legal, economic and political fields. However, not a few youths are out of the normative signs of Law No. 40 of 2009 on Youth (Al Faza, Lestari, \& Abstrak, 2020). Youth is indicated to be indifferent, indifferent, not caring to the point of understanding apathy (Oyedemi \& Mahlatji, 2016).

Apathy is the indifference of an individual in which youth do not have special attention or interest in certain aspects which according to include aspects of physical, emotional, and social life (Zulfikar \& Nasrul, 2019). Not paying attention to the above aspects intersect with other areas of social life such as social, cultural and political fields (Lestari \& Arumsari, 2018). Apathy in politics is meant as a lack of sympathy and empathy for matters of power, elections. This apathy affects 2 (two) dimensions, namely attitudes and behavior. Apathy can be in the form of disinterest in politics, distrust of political institutions and unwillingness to participate (Sarfaraz \& Khalid, 2014). Without the desire to participate, youth will miss a great opportunity to improve their skills in participating in politics (Nurgiansah, 2021) (Bastedo, Dougherty, LeDuc, Rudny, \& Sommers, 2012).

Youth who do not participate in politics will have difficulty in acquiring the skills to participate in politics as adults do today (Henn et al., 2002). In addition, youth also find it difficult to adapt their lifestyle and work to political education in the old way and also youth feel that politics is not sustainable with their daily lives. They are more interested in informal forms of politics such as politics with social issues (Al Faza et al., 2020).

There are several reasons why youth are not interested in politics, among others, as stated by Etnel that today's youth are apathetic youth. Their knowledge of politics is very little compared to the youth of the previous generation (Zulfikar \& Nasrul, 2019). Similarly, Marsh and Jones stated that youth are less involved in the political system because youth are still young, while perspectives and concerns in politics are not represented so they feel that youth cannot influence politics, including in making regulations and decision making (Parawansa, 2020). 
Talking about youth and politics is not something new to be discussed. History records the various roles of youth in Indonesian national politics. Then it was emphasized that in the long history of the country, the role of youth in Indonesian politics has experienced a dialectic with the various sociocultural contexts it faces (Hikmah, 2019), long before Indonesia's independence, youth had shown high political participation as a manifestation of the desire to free themselves from the shackles of colonialism and western imperialism (Andrew Chauke, 2020).

The simultaneous regional head elections in 2020 are a test of Indonesian politics. This simultaneous local election event involved 270 regions. The details are 9 provinces, 224 regencies, and 37 cities. There are 12 (twelve) regencies/cities in South Sulawesi Province which will re-elect regional heads for the next 5 (five) years. Quoted from the South Sulawesi KPU data, the 12 regencies or cities in South Sulawesi holding the 2020 Pilkada are Makassar, Barru, Bulukumba, East Luwu, North Luwu, Maros, Pangkajene and Islands, Selayar Islands, Tana Toraja, North Toraja, Soppeng and Gowa. Based on the results of the open plenary recapitulation and determination of the permanent voter lists (DPT) for the simultaneous regional elections in 12 regencies/cities totaling 3,390,233 voters. Consisting of $1,653,200$ male voters and 1,737,033 female voters. The highest DPT was in Makassar City with 901,087 voters, followed by Gowa Regency with 529,985 voters (Gowa KPU Data).

The simultaneous regional elections in 2020 are a historic political contestation. The contestation that was held this year was the first to be held in the midst of the Covid-19 pandemic, so on the other hand there were many challenges in organizing the election contestation. Especially in the implementation of strict health protocols. The closest impact is that the potential for the Pilkada cluster for Covid-19 patients has great potential (Nurgiansah, 2021). This simultaneous local election is also an evaluation for the organizers in increasing the level of citizen participation. In particular, participation in distributing voting rights at polling stations (TPS). Distribution of voting rights is a quantitatively measurable level of participation (Marsuki, 2015).

One of the areas that will hold simultaneous regional elections in South Sulawesi is Gowa Regency. An area that has a long history in the political arena of South Sulawesi. The political dynamics in Gowa Regency, which are quite dynamic and full of surprises, are the main attraction. Geographically, this area is in the spotlight because it is directly adjacent to and is a buffer from Makassar City. Then the political events in this area are very interesting. Especially in the Simultaneous Pilkada in 2020, Gowa Regency was only followed by one pair of 
candidates. The incumbent pair Adnan Purrichta Ichsan and Abd. Rauf Malaganni will face an empty box.

The level of public participation in exercising their right to vote in the 2015 Gowa Pilkada is decreasing (Marsuki, 2015). The results of the data recapitulation conducted by the Regional General Election Commission (KPUD) of Gowa recorded only $67 \%$ of the total 558,910 Permanent Voters List (DPT) in the 2015 simultaneous elections. From the previous target mutually agreed upon by the organizers, it was $80 \%$. Meanwhile, in the 2019 Simultaneous elections, Gowa Regency again did not reach the target voter turnout, which was $77.5 \%$. The participation rate achieved was at $76.41 \%$ of the total 556,814 voters. The total number of voters in Gowa Regency who exercised their voting rights was 425,442 voters.

Based on the participation rate of the 2015 and 2019 regional elections in Gowa district, it shows that things are not going well. Community involvement in the contest shows a downward trend. Likewise for some youths, when facing a party there are those who decide not to take a stand (Dahl et al., 2018). This means that youth are reluctant to participate and tend towards apathy in the ongoing political process (Amalia \& Gemilar, 2020). Even though one vote can determine the fate of the region in the future. The purpose of this study is to examine the political apathy that plagues youth in Gowa Regency. Then to reveal the causes of apathy and alternative solutions to these problems.

\section{RESEARCH METHODS}

This research uses a qualitative method with a case study approach. Qualitative methodology is a procedure that produces descriptive data in the form of written or oral data in the community (Moleong, 2002). Determination of informants in the study using purposive sampling technique. This technique includes people who are selected on the basis of certain criteria made by researchers based on research objectives. The informants taken consisted of elements of youth organizations, apathetic youth groups and the government. Collecting data through document studies, observation, in-depth interviews, focus group discussions and documentation. Interviews were conducted in several places such as coffee shops, cafes and the secretariat of youth organizations. The data analysis carried out refers to the model proposed by Miles and Huberman. The stages of data analysis start from data reduction, data presentation, and drawing conclusions.

\section{DISCUSSION}

One of the successes in holding a democratic party is measured by the level of political participation. Youth as a symbol of an area's civilization is expected to be the source and driver of this participation. However, in Gowa Regency there are still some youths who 
show an indifferent attitude and do not care about the stages of regional head elections. The causes of youth apathy towards politics in the youth body according to the results of this study are as follows :

\section{Weak Knowledge of the Position of Youth in Development}

Youth is an individual who when viewed physically is experiencing development and psychologically is experiencing emotional development, so that youth are human resources for development both now and in the future. As a candidate for the next generation who will replace the previous generation (Nawawi et al., 2020). Youth is the successor to the struggle of the previous generation to realize the ideals of the nation. Youth is the hope of every progress in a nation, Youth is expected to be able to change people's views of a nation and become the foundation of previous generations to develop a nation with ideas or ideas that are knowledgeable, broad insight, and based on values. and norms prevailing in society (Marsuki, Ismail, \& Mukramin, 2019).

Surbakti mentions two important variables that influence a person's level of political participation (Amalia \& Gemilar, 2020). First, the aspect of political awareness of the government (political system). Political awareness is awareness of the rights and obligations of citizens. For example, political rights, economic rights, legal protection rights, economic obligations and social obligations. Second, it concerns how to evaluate and know about government policies and government implementation. Youth's knowledge of politics greatly influences their attitude towards politics itself. If the knowledge is limited to weak then the potential for apathy is so great.

The knowledge obtained by adolescents and young people is initially limited to the results of observations of natural phenomena, society, and culture and then increases with the knowledge gained from the results of their thoughts. The same applies to knowledge about politics and regional development. General knowledge about elections and the role of youth is still limited (Andrew Chauke, 2020). The election of regional heads is simply known as choosing the regent/deputy regent. Involvement is only for those who work in that field. Youth is not included in this section.

In Gowa Regency, it was found that young people became apathetic towards politics because there was still a lack of knowledge about politics itself. Politics is only known as a means of electing regional heads, DPRD members, presidents and village heads. Apart from the others, young people still lack other information. Knowledge of something is the main trigger of interest in something (Aviani, 2020). Similar to politics, more broadly, politics is not just a matter of electoral votes. But also from another dimension, politics is a tool for making improvements and evaluating development. 


\section{Bad Political Image}

Political image is a self-image that a politician or certain group wants to show (Nur Wardhani, 2018). Recently, the political image is often discussed. Talks about political image are getting hotter in line with the incessant political campaigns carried out by the candidate pairs for regent and deputy regent. Despite being a single candidate, the team's movement was massive. Almost all mass communication spaces are filled with campaign props containing taglines and selling work programs.

The researcher finds that the political image of Gowa that has been so developed is described with negative/bad perceptions. For some youth groups who do not take part, they think that the image or face of today's politics is bad. This is obtained through experience and observations from various democratic parties that have passed. Then influenced by the political actors involved. Both the contestants themselves, political party administrators to the success teams/campaigns of the candidate pairs.

In theory Albacete says that youth's distrust of the government is also higher than that of adults (Bastedo et al., 2012). Youth are also less interested in politics and general issues. Youth knowledge about political institutions and democratic processes is also lacking because they are less interested in seeking political information and less willing to participate. In addition, the bad image of the political world continues to be internalized from time to time. In fact, youth are identified as the main figures in the performance and sustainability of the democratic system.

\section{Influence of Family / Friendship \\ Environment}

Family or more especially parents have a very important role in shaping individual political character from an early age, so that when individuals start growing up, individuals already have a mature and careful mindset to be able to make decisions and participate directly in the political realm (Ardiatma \& Septina, 2019). This is reinforced by the statement from Almond, the socialization process that occurs in the family is always unidirectional where the experience of the family has an important influence on the political secondary structure (Nurgiansah, 2021). Likewise, the political attitude of Gowa youth depends on the power structure within their respective families.

As a determining factor, family or parents must be role models for individuals. Starting from the way of speaking, how to deal with problems, to the youth's interest in politics. The role of the family or parents in political education is to provide understanding to individuals about their rights and obligations, as well as responsibilities in the life of the nation and state. Until individuals grow up, individuals must have their own awareness of their rights and obligations as 
citizens. Such as their obligation to participate in general elections and the right of youth to channel their vote.

Budiarjo says that political events or events in general as well as those that befall individuals or groups of people, whether involving the political system or political instability, political promises from candidates for leaders or candidates for people's representatives that are never kept can affect the political behavior of the people (Amalia \& Gemilar, 2020). Information on this political event was passed on by the family circle. For his family, in the past there were bad political incidents, it will be passed on to their children and families. If political events are positive, it will have an impact on participation. On the other hand, if the information provided tends to be a bad experience, distrust and uninvolvement in political contestation will build.

Similar to what has been expressed by Surbakti that the political attitudes of young people as well as their political choices, are influenced by the social environment and the political environment where long socialization takes place, there are various transfers of values in this group and social environment (Sarfaraz \& Khalid, 2014). The social environment of young voters also provides various information related to the building of their cognition. This will later affect the political attitudes of young people and their political choices. The political choice of a candidate is greatly influenced by information on his social environment.

\section{Contestants Are Only Followed By One Pair Of Candidates}

This year's Pilkada Kab. Gowa feels different. Besides being carried out in an atmosphere of Covid-19, it is also only followed by one pair of candidates. Based on the results of the determination by the Gowa KPUD, until the deadline for registration only one pair of candidates. The pair are incumbent Adnan Purrichta Ichsan and Abd Rauf Malaganni. The support of the majority of political parties in Gowa joined in it. This year's Pilkada residents of Gowa Regency were presented with something unusual. This incumbent pair will only be paired with an empty box. Of course victory is in hand. But it affects the psychology of voters. This single candidate phenomenon makes people's choices narrow to 2 (two) choices. For those who want the incumbent to return to power, they will reelect Adnan Purrichta Ichsan and Abd. Rauf Malaganni. But on the other hand, they can choose an empty box and not channel their voting rights.

Among the youth of Gowa this single candidate phenomenon is influential. The involvement of youth in politics is reduced. Apathy is unavoidable. The youth considers that the Pilkada this time is different. This election is not interesting. Only one pair of candidates so not challenging. The end result 
is clear. Then the figures involved are not other people. The figures for the current election candidate pair are part of the Yasin Limpo clan that has been in power in Gowa Regency since 25 years ago. The track record is known. Both in terms of success and other oblique news.

Then alternative solutions that can be done to minimize apathy are to increase education or community-based political socialization and strengthen youth organizations as a forum for youth to develop themselves (Acuña-Duarte, 2017). As a note for researchers, at the moment of election information on politics is very easy to find. Banners, meetings, political discussions are very lively. However, after the election, this is no longer the case. Political outreach and education were only intense at a time. The rest is not as massive as during the Pilkada season.

Apathy can certainly have a negative impact on several things, especially regarding political and economic issues. The impact is socially irresponsible / apathetic. This is as stated by Solmitz, passive, submissive and even numb, especially to matters relating to social, economic, environmental, and political issues (Oyedemi \& Mahlatji, 2016). Symptoms of this apathy can be seen from the lack of awareness, concern and even social irresponsibility that can affect voting (Amalia \& Gemilar, 2020). If it is related to the results of the research, it is in accordance with some of the youth of Gowa Regency indicated that they have a lack of awareness of their responsibilities as citizens who experience indifference to issues that continue to develop, especially regarding social, political, and economic issues.

\section{CONCLUSION}

The results of the research and discussion that have been compiled by researchers, it can be concluded that political apathy is the indifference of an individual who does not have special attention or interest in politics. Youth in Gowa Regency, who are the continuation of the development relay, are not immune from apathy. Youth apathy towards politics in Gowa Regency is motivated by several factors, including weak knowledge of the position of youth in development, bad political image, influence of family/friendship environment and contestants are only followed by one pair of candidates. Then alternative solutions that can be done to minimize apathy are to increase education or community-based political socialization and strengthen youth organizations as a forum for youth to develop themselves. This political education and socialization is not only carried out during the regional head election stage. However, it must be done after the democratic party ends.

\section{REFERENCES}

[1] Acuña-Duarte, A. A. (2017). Electoral apathy among Chilean youth: New evidence for the voter registration dilemma. Estudios Gerenciales, 33(145), 341-351. https://doi.org/10.1016/j.estger.2017.11.005

[2] Al Faza, F., Lestari, D. P., \& Abstrak, I. A. (2020). Sikap Apatis Pemuda terhadap Politik 
di Dusun Mekarsari Desa Kalibeber Kecamatan Mojotengah Kabupaten Wonosobo. Unnes Political Science Journal, 4(2), 51-54. https://doi.org/10.15294/upsj.v4i2.26219

[3] Amalia, A. N., \& Gemilar, M. (2020). MERETAS GENERASI APOLITIS PADA PEMILIH PEMULA MELALUI PENDIDIKAN POLITIK HACKING. Jurnal Pettarani Election Review, 1(2), 126-142.

[4] Andrew Chauke, T. (2020). Youth apathy in an electoral democracy: a critical discourse on civil participation in South Africa. African Journal of Gender, Society and Development (Formerly Journal of Gender, Information and Development in Africa), 9(3), 35-51. https://doi.org/10.31920/2634$3622 / 2020 / 9 n 3 a 2$

[5] Ardiatma, E., \& Septina, W. E. (2019). Peran Pemuda Dalam Pilkada Serentak. Jurnal Ilmu Politik Dan Ilmu Pemerintahan, 05(02), 8092.

[6] Aviani, R. R. (2020). PENGARUH MODERNISASI TERHADAP SEMANGAT NASIONALISME DAN GOTONG ROYONG PADA GENERASI MUDA.

[7] Agustang, A. (2020). Symbolic Violence towards Students in the Context of the Existence of the Stereotypical Frames of Lecturers and Students in the Higher Education System in Indonesia. PalArch's Journal of Archaeology of Egypt/Egyptology, 17(2), 249-258

[8] Agustang, A. (2020). The Symbolic Violence Towards Private School Students Through The Frame Stereotype In Bantaeng District Of Indonesia. Prosiding ICoISSE, 1(1), 578588

[9] Bastedo, H., Dougherty, I., LeDuc, L., Rudny, B., \& Sommers, T. (2012). Youth, Democracy and Civic Engagement: The 'Apathy is Boring' Surveys. Annual Meeting of the Canadian Political Science Association, 1-32. Retrieved from http://www.cpsa-acsp.ca/papers2012/Leduc.pdf

[10] Dahl, V., Amnå, E., Banaji, S., Landberg, M., Šerek, J., Ribeiro, N., ... Zani, B. (2018).
Apathy or alienation? Political passivity among youths across eight European Union countries. European Journal of Developmental Psychology, 15(3), 284-301. https://doi.org/10.1080/17405629.2017.1404 985

[11] Henn, M., Weinstein, M., \& Wring, D. (2002). A Generation Apart? Youth and Political Participation in Britain. The British Journal of Politics and International Relations, 4(2), 167-192. https://doi.org/10.1111/1467-856x.t01-100001

[12] Hikmah, A. (2019). Partisipasi Pemuda Dalam Kontestasi Politik Di Kabupaten Maros (Studi Kasus: Pemilihan Calon Anggota Legisltif Tahun 2019). Universitas Hasanuddin. Retrieved from http://jurnal.globalhealthsciencegroup.com/i ndex.php/JPPP/article/download/83/65\%0Ah ttp://www.embase.com/search/results?subact ion=viewrecord \&from=export\&id=L603546 864\%5Cnhttp://dx.doi.org/10.1155/2015/420 723\%0Ahttp://link.springer.com/10.1007/97 8-3-319-76

[13] Lestari, E. Y., \& Arumsari, N. (2018). Partisipasi Politik Pemilih Pemula pada Pemilihan walikota semarang di kota semarang. Integralistik, 1, 63-72.

[14] Marsuki, N. R. (2015). “ Eranya Anak Muda "Partisipasi Politik Pemuda: Kasus pada Pilkada Kabupaten Gowa Tahun 2020. Jurnal Ibnu Khaldum.

[15] Marsuki, N. R., Ismail, L., \& Mukramin, S. (2019). Upacara Mangrara Banua Tongkonan dalam Makna Sosial. Phinisi Integration Review, 2(1).

[16] Nawawi, M., Ali, A., Irawan, B., Ahmad, B., Mukramin, S., Marsuki, N. R., ... Kaya, I. R. G. (2020). The village kalesang program as a poverty alleviation community. International Journal of Scientific and Technology Research, 9(3), 3103-3107.

[17] Nur Wardhani, P. S. (2018). Partisipasi Politik Pemilih Pemula dalam Pemilihan Umum. Jupiis: Jurnal Pendidikan Ilmu-Ilmu Sosial, $\quad 10(1), \quad 57$. https://doi.org/10.24114/jupiis.v10i1.8407

[18] Nurgiansah, T. H. (2021). Petuah Pendidikan 
Kewarganegaraan Dalam Kontestasi Politik. Academy of Education Journal, 12(1), 39-47. https://doi.org/10.47200/aoej.v12i1.423

[19] Oyedemi, T., \& Mahlatji, D. (2016). The 'Born-free' Non-voting Youth: A Study of Voter Apathy Among a Selected Cohort of South African Youth. Politikon, 43(3), 311323.

https://doi.org/10.1080/02589346.2016.1160 857

[20] Parawansa, K. I. (2020). Hambatan terhadap Partisipasi Politik. In Academia.

[21] Sarfaraz, A., \& Khalid, A. (2014). Reasons for Political Interest and Apathy among University Students: A Qualitative Study Political Interest and Apathy View project Customer Services in Pakistan View project. Pakistan Journal of Social and Clinical Psychology 2012, 10(1), 61-67. Retrieved from

https://www.researchgate.net/publication/26 0171871

[22] Zulfikar, \& Nasrul. (2019). PERSEPSI PEMUDA TERHADAP PEMILIHAN UMUM LEGISLATIF PADA TAHUN 2019 DI KECAMATAN MILA KABUPATEN PIDIE. Jurnal Sains Riset (JSR), 9(September 2019), 61-67.

[23] Lexy. Moleong, J. (2002). Metodologi Penelitian Kualitatif. Bandung : Remaja Rosdaya 